Supporting Information

for

\title{
Signal-On Protein Detection via Dye Translocation between Aptamer and Quantum Dot
}

Yeh-Hsing Lao ${ }^{1 \S}$, Chun-Wei Chi ${ }^{2}{ }^{\S}$,, Sarah M. Friedrich ${ }^{3}$, Konan Peck ${ }^{4}$, Tza-Huei Wang ${ }^{3,5}$, Kam W. Leong ${ }^{1 *}$, and Lin-Chi Chen ${ }^{2 *}$

1 Department of Biomedical Engineering, Columbia University, New York NY 10027, USA

2 Department of Bio-Industrial Mechatronics Engineering, National Taiwan University, Taipei 10617, Taiwan

3 Department of Biomedical Engineering, Johns Hopkins University, Baltimore MD 21218, USA

4 Institute of Biomedical Sciences, Academia Sinica, Taipei 11529, Taiwan

5 Department of Mechanical Engineering, Johns Hopkins University, Baltimore MD 21218, USA

$\S$ Contributed equally

ๆ Present address: Department of Biomedical Engineering, City College, The City University of New York, New York NY 10031, USA

*Corresponding author: Dr. Kam W Leong (kam.leong@ columbia.edu) or Dr. Lin-Chi Chen (chenlinchi@ntu.edu.tw)

\section{Contents}

Page S-1 - Fluorescent spectra of QD and YOYO-3 absorbed QD complex

Page S-2 - FRET spectra of QD-HTQ37/YOYO-3:HTDQ29 in response to thrombin and BSA

Page S-3 - Thrombin detection in the presence of human serum

Page S-4 - Dye translocation between HTDQ29 and QD-HTQ37 in the presence or absence of thrombin

Page S-5 - Dye translocation between HTQ37 and QD-HTQ37 in the presence or absence of thrombin

Page S-6 - Summary of the published aptameric QD beacons 


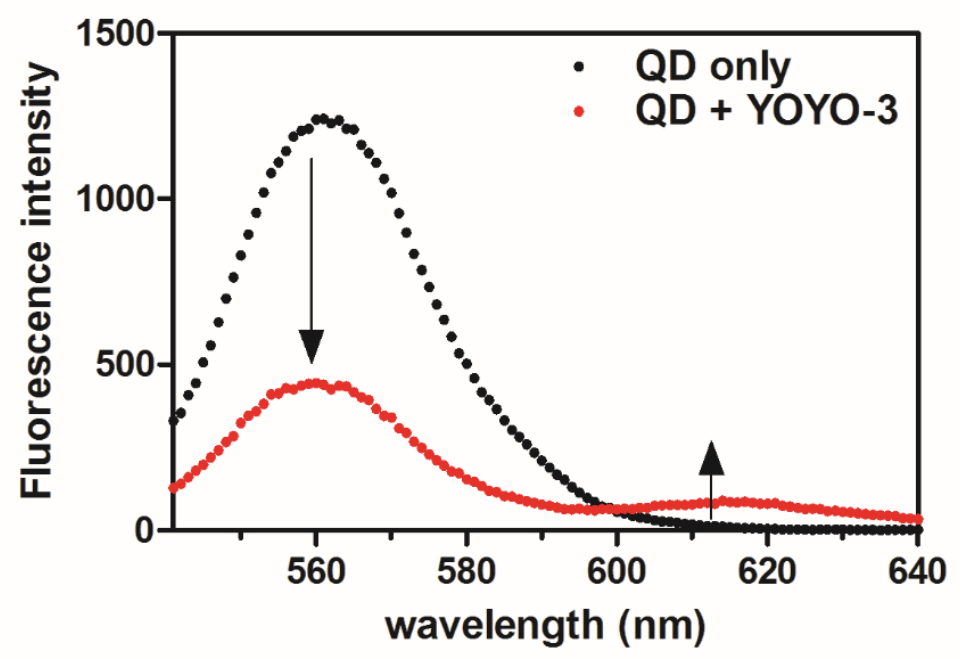

Figure S1. Fluorescent spectra of QD and YOYO-3-absorbed QD. Carboxyl-QD (15 nM) was incubated with or without $100 \mathrm{nM}$ of YOYO-3 in PBS for $1 \mathrm{hr}$ at RT. The mixture was transferred to a 96-well opaque plate. The emission from 541 to $649 \mathrm{~nm}$ was recorded with an excitation at $365 \mathrm{~nm}$. 


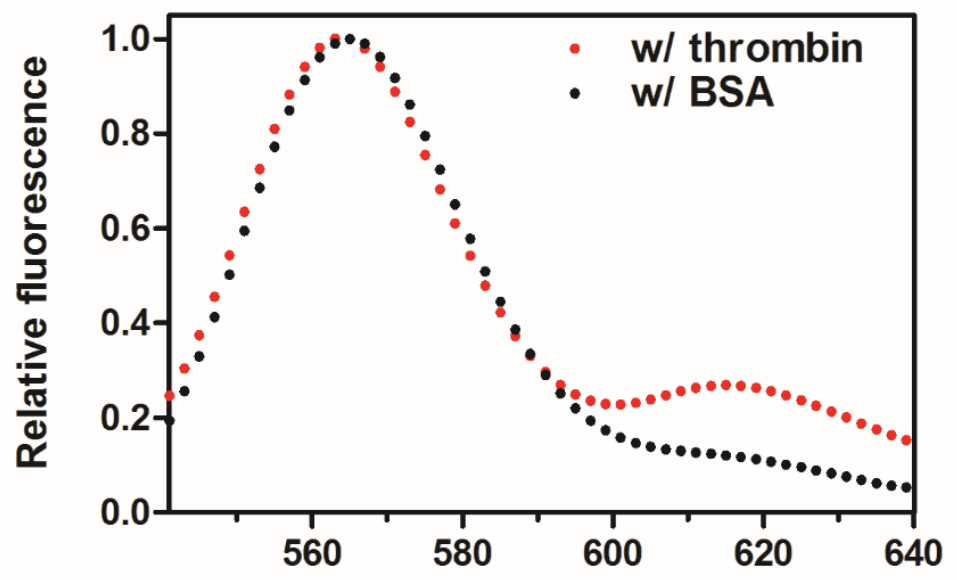

Figure S2. FRET spectrum of QD-HTQ37+YOYO-3:HTDQ29 in response to $500 \mathrm{nM}$ of thrombin or BSA. 


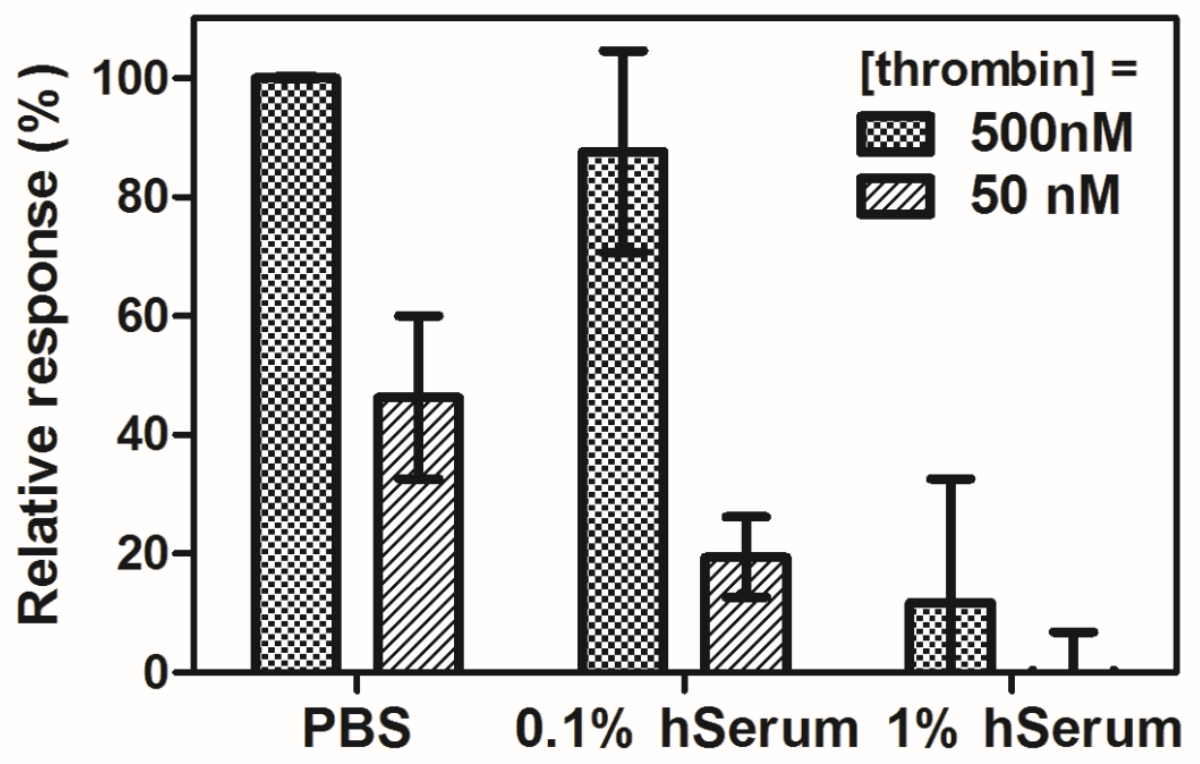

Figure S3. Thrombin detection in the presence of human serum. The signal was normalized as percentage $(\%)$ of the signal with $500 \mathrm{nM}$ thrombin in PBS. Data are represented as mean \pm SEM $(n=3)$. 


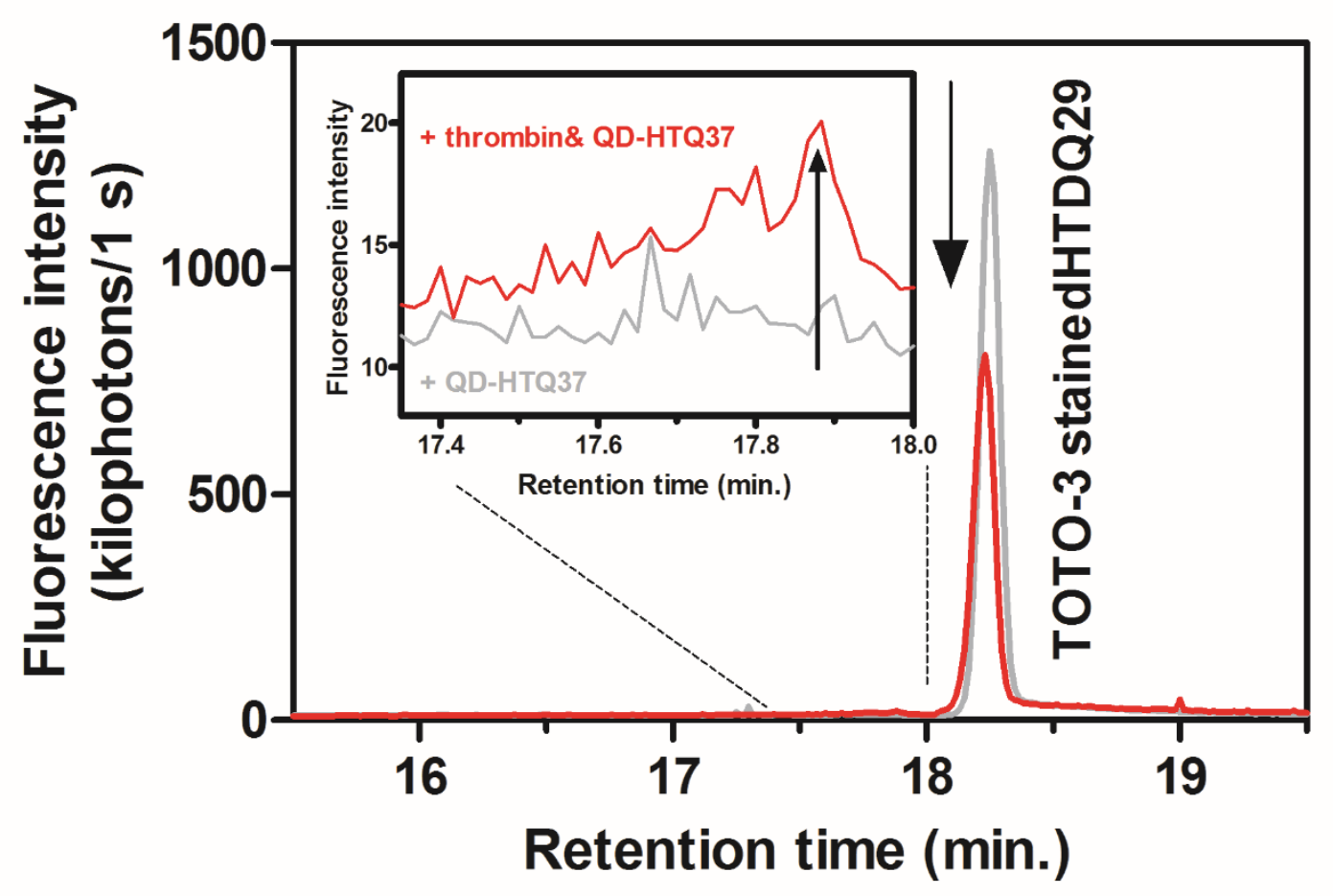

Figure S4. Dye translocation between HTQ29 and QD-HTQ37 in the absence and presence of thrombin. HTDQ29 $(1.67 \mu \mathrm{M})$ was first stained with $1.67 \mu \mathrm{M}$ of TOTO-3, and then incubated with $15 \mathrm{nM}$ of QDHTQ37 with or without thrombin $(500 \mathrm{nM})$ for $30 \mathrm{~min}$ at RT. Subsequently, the sample was separated and the TOTO-3 signal was measured on the CICS platform. 


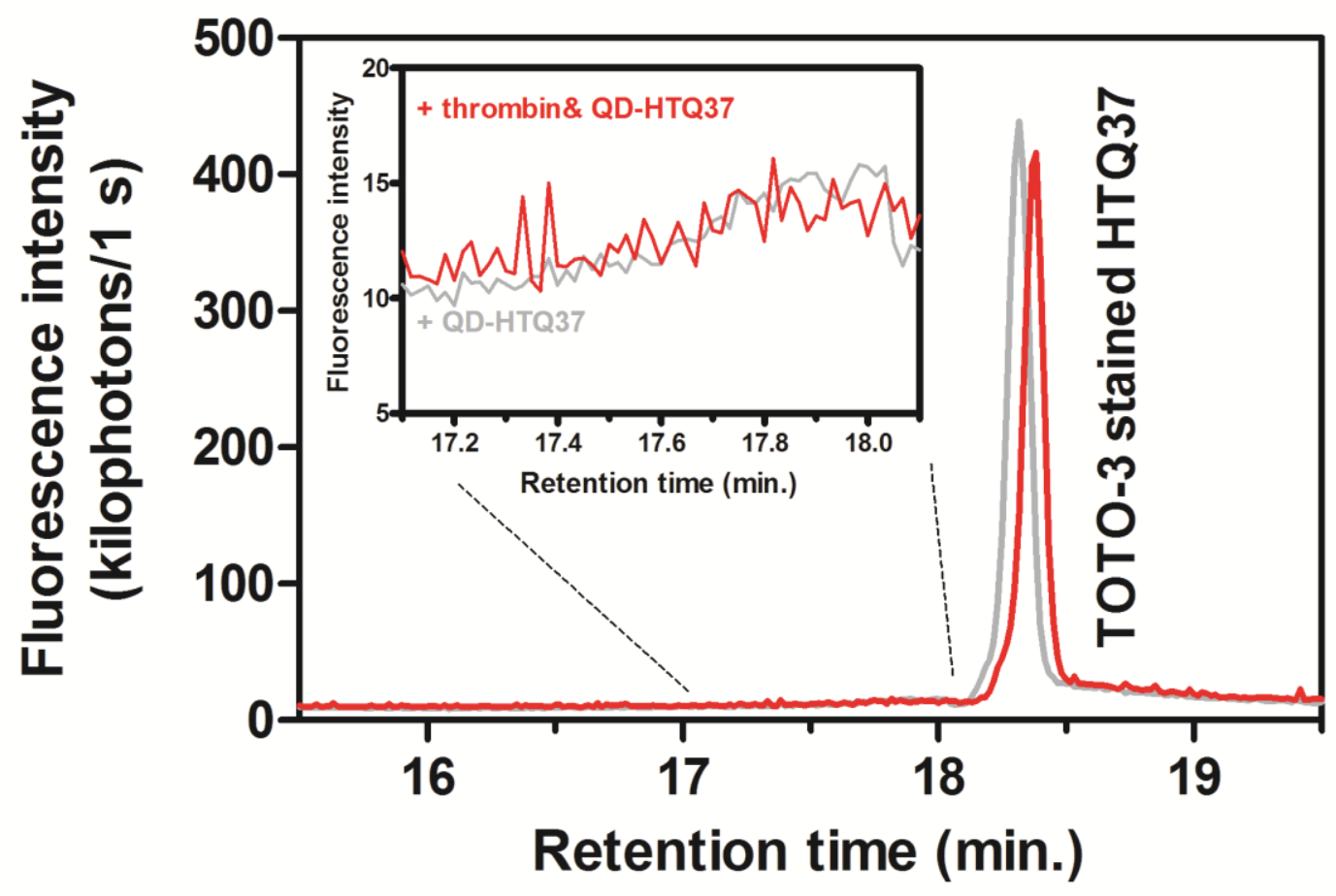

Figure S5. Dye translocation between two identical aptamer pair (HTQ37 and QD-HTQ37). HTQ37 (1.67 $\mu \mathrm{M})$ was first stained with $1.67 \mu \mathrm{M}$ of TOTO-3, and then incubated with $15 \mathrm{nM}$ of QD-HTQ37 with or without thrombin $(500 \mathrm{nM})$ for 30 min at RT. Subsequently, the sample was separated and the TOTO-3 signal was measured on the CICS platform. 
Table S1 Comparison between the reported QD-aptamer beacons and the design demonstrated in this study

\begin{tabular}{|c|c|c|c|c|c|c|}
\hline FRET Acceptor & Sensing mechanism & Signal output & Target & LOD & $\begin{array}{l}\text { Distinct pair } \\
\text { screening? }\end{array}$ & Ref. \\
\hline Eclipse quencher & $\begin{array}{l}\text { Reporter strand } \\
\text { displacement }\end{array}$ & Signal-on & Thrombin & $-*$ & No & 18 \\
\hline $\begin{array}{l}\text { Ethidium bromide } \\
\text { and Atto- } 647 \mathrm{~N}\end{array}$ & $\begin{array}{l}\text { Reporter strand } \\
\text { displacement }\end{array}$ & Signal-on & Thrombin & $30 \mathrm{pM}$ & No & 19 \\
\hline $\begin{array}{l}\text { Black hole } \\
\text { quencher }\end{array}$ & $\begin{array}{l}\text { Reporter strand } \\
\text { displacement }\end{array}$ & Signal-on & PDGF-BB & $0.4 \mathrm{nM}$ & No & 20 \\
\hline $\begin{array}{l}\text { Cy5 and Iowa } \\
\text { Black RQ }\end{array}$ & $\begin{array}{l}\text { Reporter strand } \\
\text { displacement }\end{array}$ & Signal-on & Cocaine & $\begin{array}{l}500 \\
\mathrm{nM}\end{array}$ & No & 21 \\
\hline $\begin{array}{l}\text { Black hole } \\
\text { quencher }\end{array}$ & $\begin{array}{l}\text { Reporter strand } \\
\text { displacement }\end{array}$ & Signal-on & VEGF & $1 \mathrm{nM}$ & No & 22 \\
\hline Cy5 & $\begin{array}{l}\text { Reporter strand } \\
\text { association }\end{array}$ & Signal-off & VEGF & $12 \mathrm{nM}$ & No & 22 \\
\hline Iowa Black FQ & $\begin{array}{l}\text { Reporter strand } \\
\text { association }\end{array}$ & Signal-off & Mucin 1 & $\begin{array}{l}250 \\
\mathrm{nM}\end{array}$ & No & 23 \\
\hline Cy3 & $\begin{array}{l}\text { Reporter strand } \\
\text { displacement }\end{array}$ & Signal-off & ATP & $10 \mathrm{pM}$ & No & 24 \\
\hline BOBO-3 & $\begin{array}{l}\text { FRET acceptor } \\
\text { dissociation }\end{array}$ & Signal-off & Thrombin & $1 \mathrm{nM}$ & No & 25 \\
\hline $\begin{array}{l}\text { Carbon } \\
\text { nanoparticle }\end{array}$ & $\begin{array}{l}\text { FRET acceptor } \\
\text { dissociation }\end{array}$ & Signal-on & Thrombin & $13 \mathrm{pM}$ & No & 26 \\
\hline $\begin{array}{l}\text { Carbon } \\
\text { nanoparticle }\end{array}$ & $\begin{array}{l}\text { FRET acceptor } \\
\text { dissociation }\end{array}$ & Signal-on & Insulin & $-*$ & No & 27 \\
\hline $\mathrm{Ru}(\mathrm{bpy})_{2}(\mathrm{dppz})^{2+}$ & Dye translocation & Signal-off & Thrombin & $50 \mathrm{nM}$ & No & 28 \\
\hline YOYO-3 & Dye translocation & Signal-on & Thrombin & $10 \mathrm{nM}$ & Yes & $\begin{array}{l}\text { This } \\
\text { work }\end{array}$ \\
\hline
\end{tabular}

\footnotetext{
* Not reported
} 